$12-2016$

\title{
The 1994 Rwandan Genocide: The Religion/Genocide Nexus, Sexual Violence, and the Future of Genocide Studies
}

Kate E. Temoney

Montclair State University

Follow this and additional works at: https://digitalcommons.usf.edu/gsp

\section{Recommended Citation}

Temoney, Kate E. (2016) "The 1994 Rwandan Genocide: The Religion/Genocide Nexus, Sexual Violence, and the Future of Genocide Studies," Genocide Studies and Prevention: An International Journal: Vol. 10: Iss. 3: 3-24.

DOI:

http://doi.org/10.5038/1911-9933.10.3.1351

Available at: https://digitalcommons.usf.edu/gsp/vol10/iss3/4

This Articles is brought to you for free and open access by the Open Access Journals at Digital Commons @ University of South Florida. It has been accepted for inclusion in Genocide Studies and Prevention: An International Journal by an authorized editor of Digital Commons @ University of South Florida. For more information, please contact digitalcommons@usf.edu. 


\title{
The 1994 Rwandan Genocide: The Religion/Genocide Nexus, Sexual Violence, and the Future of Genocide Studies
}

\author{
Kate E. Temoney \\ Montclair State University \\ Montclair, New Jersey, USA
}

\begin{abstract}
In recent genocides and other conflicts-for example, the Sudan, Burma, and now Iraq-sexual violence and religion have received increasing but modest systematic treatment in genocide studies. This essay contributes to the nascent scholarship on the religious and sexual dimensions of genocide by providing a model for investigating the intersections among religion, genocide, and sexual violence. I treat the Rwandan genocide as a case study using secondary and primary sources and proffer the reinforcing typologies of "othering," justification, and authorization as an investigatory tool. I further nuance the influences of religion on forms of sexual violation by arguing that religion indirectly (distally) and directly (proximately) furthers the aims of genocide by coding genocidal ideology and violence as "religious." Ultimately, I contend that studying the religious and sexual aspects of genocide deepens our understanding of the complex dynamics of genocide and opens new lines of inquiry into genocide studies.
\end{abstract}

Keywords: Rwanda, genocide, sexual violence, religion

In the 1990s, sexual violence was recognized by international tribunals as a weapon of war. ${ }^{1}$ In recent genocides and other conflicts-such as those in the Sudan, Burma, and now Iraq-rape as well as the religious aspects of these conflicts have received increasing but modest systematic attention. As a contribution to the nascent scholarship in genocide studies on the religious and sexual dimensions of genocide, I treat the Rwandan genocide as a case study. Although considerable scholarship exists on the role of religion and rape in the Rwanda, most notably, Christianity and Genocide in Rwanda (2009) by Timothy Longman, and Sacrifice as Terror: The Rwandan Genocide of 1994 (2001) by Christopher C. Taylor, my goal is to examine the mutually reinforcing relationships among genocide, religion, and sexual violence. In doing so, Longman's work is augmented to include not only how Christian beliefs, but also traditional Rwandan beliefs (as well as a syncretism of the two) enabled the genocide. Further, Taylor's work is extended to include how not only Rwandans indigenous beliefs but Christian beliefs and leadership encouraged rather than discouraged rape. Ultimately, the aim of this article is to build a generalizable schema that assists in clarifying the intersections of genocide, religion, and sexual violence in the interest of genocide prevention as well as prosecution efforts.

In 1994, the Hutu Power elite propagandists called for the immediate expulsion of all Tutsi from Rwandan soil, a numerical and civilly oppressed minority. Ideologues convinced and mobilized the Hutu citizenry that they had to defend themselves from Tutsi-an alien threat from Ethiopia-who supposedly assassinated the Rwandan Hutu president, Juvénal Habyarimana, and were in league with the invading Rwandan Patriotic Front (RFP) from the north in Uganda. Using secondary literature and primary data in the form of public speeches and documents, victim accounts, and International Criminal Tribunal for Rwanda (ICTR) transcripts, I delineate and illustrate the intersections of genocide, religion, and sexual violence as a model for examining the Rwandan genocide as well as other past and contemporary genocides. First, I propose nexuses of religion and genocide via the typologies of othering, justification, and authorization, and second, I explore the distal (indirect) and proximate (direct) influence of religion on genocidal sexual violence guided by the three aforementioned typologies. Last, I review the implications of the study of the Rwandan genocide, specifically, for future genocide studies as well as general recommendations for genocide research and prevention.

\footnotetext{
${ }^{1}$ In the 1996 ICTY case, Prosecutor $v$. Tadic, Dusko Tadic was charged with rape and sexual violence as a crime against humanity as well as a war crime. Tadic was not convicted of rape, but he was convicted of aiding and abetting crimes of sexual nature. The landmark decision was official recognition by the United Nations Courts of rape as a war crime. See Marlise Simons, “U.N. Court, for the First Time, Defines Rape as War Crime," New York Times, June 28, 1996, accessed August 18, 2016, http://www.nytimes.com/1996/06/28/world/un-court-for-first-time-defines-rape-as-warcrime.html
}

Kate E. Temoney, "The 1994 Rwandan Genocide: The Religion/Genocide Nexus, Sexual Violence, and the Future of Genocide Studies" Genocide Studies and Prevention 10, 3 (2016): 3-24. @2016 Genocide Studies and Prevention. 


\section{Religion and Genocide}

Genocide is not aleatoric nor are its accounts monocausal, and although religious antagonism is rarely the motivation for undertaking genocide, religious worldviews, rhetoric, and rituals are often enlisted in the planning and execution of a genocidal conflict. ${ }^{2}$ It is typically accepted that "religious violence seldom has its cause in purely religious conflicts; usually it occurs in the context of a clash between secular social interests." ${ }^{3}$ The religious nature of genocide resides in the "meaning that actors ascribe to it...[and] the specific expectation[s] on the part of the actor[s] (emphasis added)." Moreover, "given the function of religion as a means for understanding what appears to be beyond the reach of understanding, the use of religious reservoirs of meaning and value may seem to make eminent sense." ${ }^{5}$ Hence, referring to Max Weber, David Little writes, "human beings seem compelled to evaluate given political and economic arrangements in reference to sacred or cosmic standards. ${ }^{6 "}$ Bruce Lincoln specifies these standards when he avers that "certain kinds of religious discourse can assist in [morally justifying]...otherwise problematic acts as righteous deeds, sacred duties, or the like, as when killing is defined as sacrifice, destruction as purification, or war as Crusade." ${ }^{7}$ Extending this logic to genocide, "those who commit genocide often endow their actions with some sort of religious meaning, frequently putting forth the assertion that, in destroying entire groups of people, they are doing God's work." ${ }^{8}$

Henry R. Huttenbach succinctly summarizes the intersection and consequence of religion and genocide when he writes,

[R]eligion - meaning the faithful, the doctrine, the clergy and their institutions - can easily be prompted to buttress genocidal thought and action in a wide array of capacities. The religiongenocide nexus...in particular, must be carefully monitored in times of social crisis... It is the task of scholars to expose and explore it, and for policy makers to dismantle the religion-genocide connection [emphasis added]. ${ }^{9}$

Responding to Huttenbach's admonishment entails not only examining religion as a tradition of the faithful who ascribe to particular beliefs and practices and form institutions that propagate them but also as a functional ideology, one that can make the unthinkable act of genocide thinkable by styling extirpation as a moral obligation indispensible to reimagining a community that is divinely ordained and cosmologically necessary. To be sure, in agreement with Scott Appleby's position, religion has the potential to further peacemaking, but religion has also "so often inspired, legitimated, and exacerbated deadly conflicts," ${ }^{\prime 10}$ and it is the latter capacity of religion that is our focus. A study

\footnotetext{
2 "Religion" is not being treated as a reified concept with its own agency, but as a worldview and ideology that is expressed by believers, ecclesial actors, and institutions in the forms of religious rhetoric, appeals to the myths and dogma, and ritual practices. My use of the term "genocide" refers to the 1948 United Nations Convention on the Crime of Genocide: "Genocide means any of the following acts committed with the intent to destroy, in whole or in part, a national, ethnic, racial or religious group, as such: (a) Killing members of the group; (b) Causing serious bodily or mental harm to members of the group; (c) Deliberately inflicting on the group conditions of life calculated to bring about its physical destruction in whole or in part; (d) Imposing measures intended to prevent births within the group; (e) Forcibly transferring children of the group to another group."

${ }^{3}$ Hans G. Kippenberg, Violence as Worship: Religious Wars in the Age of Globalization (Stanford: Stanford University Press 2011), 13 .

${ }^{4}$ Ibid., 14 .

${ }^{5}$ Thomas Brudholm and Thomas Cushman, "Introduction: The Religious in Responses to Mass Atrocity" in The Religious in Responses to Mass Atrocity: Interdisciplinary Perspectives, eds. Thomas Brudholm and Thomas Cushman (Cambridge University Press, 2009), 4.

${ }^{6}$ David Little, "Studying 'Religious Human Rights': Methodological Foundations," in Religious Human Rights in Global Perspective, eds. Johan D. van der Vyver and John Witte, Jr. (Hague: Martinus Nijhoff Publishers, 1996), xx.

${ }^{7}$ Bruce Lincoln, Holy Terrors: Thinking about Religion after September 11 (Chicago: The University of Chicago Press, 2006$), 94$.

${ }^{8}$ David Patterson, "Getting Rid of the G-d of Abraham: A Prerequisite for Genocide," in Confronting Genocide: Judaism, Christianity, Islam, ed. Steven d Leonard Jacobs (Lanham, MD: Lexington Books, 2009), 210.

${ }^{9}$ Steven Leonard Jacobs, "Introduction: Genocide in the Name of God: Thoughts on Religion and Genocide, in Confronting Genocide: Judaism, Christianity, Islam, ed. Steven Leonard Jacobs (Lanham, MD: Lexington Books, 2009), ix.

${ }^{10}$ Scott R. Appleby, The Ambivalence of the Sacred: Religion, Violence, and Reconciliation (Lanham: Rowan \& Littlefield
} 
of the Rwandan genocide locates three possible nexuses of religion and genocide, in its destructive capacity, in othering, justification, and authorization. These nexuses are not mutually exclusive, as they overlap and reinforce each other in significant ways, but singling each of these nexuses out for consideration as ideal types provides a starting point for investigating the complexity of their interaction. These three nexuses were at play in Hutu propagandists mobilizing the civilian population by revising and exploiting colonial inspired biblical myths as well as indigenous cosmological beliefs in service to dehumanizing Tutsi by characterizing them as a radical, alien other; justifying their elimination due to a threat they posed to the temporal and atemporal order; and authorizing their extirpation as granted by the state as well as clergy and the institutional churches. Clergy largely remained silent during the genocide or actively endorsed the genocide by refusing to break alliances with the state apparatus that perpetrated genocide; at times, clergy actively participated in the orchestration and killing of Tutsi. What an examination of religious rhetoric and religious figures can do particularly well is demonstrate how the self-conferring authority of religious language and officials presents genocide as instrumental to reconfiguring communities based on divine sanction, otherworldly considerations, and a notion of a perceived threat to a cosmic order. Religious discourse and symbols, reinforced by religious authorities, can sustain perpetrator motivation by adhering to a religious rationality that resists critique from those outside of the logic of a community's religious ethos. Within this logic, the fulfillment of an obligation to bring about a higher purpose would be a must, irrespective of the cost.

\section{The Nexuses of Religion and Genocide \\ Othering}

The social organization of pre-colonial Rwanda consisted of the statuses of Hutu, Tutsi, and Twa as dictated by one's position in the political and economic community. The Tutsi $(14 \%$ of the populace) were the ruling group due to their wealth via cattle ownership; the Hutus (85\%) were mainly agriculturalists; and the Twa (1\%) were hunter-gatherer potters (not incidentally, these same percentages and vocations reflect the census data of the 1990s in Rwanda). According to traditional Rwandan societal arrangements, a group's status could change through the process of icyihuture, the acquiring of cattle, which effectively changed one's status to that of a Tutsi. Within this stratified system existed a common language and religion, a governing arrangement of chieftaincies designed to diffuse political power, and the frequent occurrence of intermarriage. ${ }^{11}$ After the arrival of European colonials, the fluid statuses of Hutu/Tutsi/Twa became solidified, adversarial racial identities. When the League of Nations stripped Germany of its colonies after World War I, Belgium gained control of what was known then as Ruanda-Urundi, and the system of racialized, fixed identities remained in place. The colonial influence of Germany and Belgium branded Tutsi as superior to Hutus because of their affluent livestock ownership within a sophisticated political system, slender features, and tall height-characteristics that Europeans attributed to Caucasian influence. Informed by Victorian conceptualizations of race, missionaries went about accounting for this influence by theorizing that Tutsi were not really Africans but settlers of Rwanda who conquered the Hutus and were of Hamitic origin, possibly descendants of a lost tribe of Israel, and the Hamitic myth was born.

The Hamitic myth derives its name from the Old Testament account of an incident involving Noah and his sons, one of whom was named Ham. According to Genesis 5, Noah's sons found him inebriated and naked. While Noah's two other sons, Japheth and Shem, respectfully averted their eyes in the act of covering their father's nakedness so as not to see his shame, Ham did not look away. For this defiance, Noah cursed Ham's son, Canaan, as well as Canaan's descendants, who were condemned to a life of servitude. In order to reconcile how the cursed, Negroid descendants of Ham could produce the Caucasian-like ruling class of Tutsi, the Hamitic hypothesis underwent revision in the nineteenth century. Ham's son Canaan was cursed, but this was not the case regarding Ham himself or his other sons, Cush, Mizrahim and Put. Therefore, Tutsi were Hamites

Publishers, 2000), 7.

${ }^{11}$ Christopher C. Taylor, Sacrifice as Terror: The Rwandan Genocide of 1994 (New York: Berg Publishers, 1999$), 145$. 
but not Negroid and were black-skinned due to intermingling with the conquered Negroids of Egypt. ${ }^{12}$ That Tutsi are from the land of Ham (Egypt) and thereby not indigenous to Rwanda is the source of the belief that Tutsi are foreign to Rwanda, and it was at the core of the ideology of the 1994 genocide.

By 1959, after decades of indirect rule by German and Belgian colonials through the minority Tutsi (who Europeans deemed as predisposed to rule because of the presumption that Tutsi retained Caucasian attributes from their ancestor, Ham), Tutsis had become the sole ruling class. However, those same colonizers then replaced Tutsi leaders with Hutu ones after Hutus began to resist, a violent campaign against Tutsi known as the 1959 Hutu Revolution or Wind of Destruction. ${ }^{13}$ As a result, thousands of Tutsi fled to Uganda or were killed. The 1994 genocide was not simply a mimesis of prior targeted killings, but a revelation of a cultural habitus. This habitus is most transparently articulated in the frequent references by Hutu extremists in the days leading up to the genocide that expressed a resentment of perceived Tutsi foreignness and their necessary eradication. Genocide inciters often made explicit references to the Hamitic myth and its effect on Rwandan culture to provide a gravity and framework for relaying the ultimate otherness of Tutsi as alien to Rwanda. For example, the mythic Hamite lineage of Tutsi was invoked in a public speech by Hutu genocide ideologue, Leon Mugesera, ${ }^{14}$ when he stated that Tutsi "should be 'sent back down the Nile,"'15 and extremists expressed their regret over their "failure to purify the country entirely... [as] they had not gone far enough in 1959 ... [in ridding] Rwanda of its polluting internal other once and for all."16

Despite decades of intermarriage, a common language, common culture, and religion $(90 \%$ of Rwandans identified as Christians prior to the genocide), historically colonial Belgian-issued identity cards, a history of colonial powers politically backing Tutsi, and Hutu propaganda fomented a resentment that led Tutsi and Hutus to see themselves as distinct from each other. ${ }^{17}$ The case of Rwanda, then, provides us with an interesting example of how othering does not need to be connected to alterity. Instead of, for example, religious difference functioning as a demarcation of the enemy (as is commonly the case in situations of conflict), in Rwanda a common religious system functioned as the basis for sustaining narratives of legitimacy and illegitimacy. The common system exploited shared religious tropes as well as the potency of religious symbols. Sigmund Freud encapsulated this phenomenon of volatility among similar peoples in his conceptualization of the "narcissism of minor differences."18 Anton Blok recounts Freud's sentiment when he writes that "people are separated from one another by a 'taboo of personal isolation,' and that it is precisely the minor differences between people who are otherwise alike that form the basis of feelings of strangeness and hostility between them." ${ }^{19}$ Blok observes that Pierre Bourdieu in his 1979 work, La Distinction, concurs with Freud (without an explicit reference to Freud), since Bourdieu "emphasized the importance of minor differences for the formation and maintenance of identity

\footnotetext{
${ }^{12}$ Mahmood Mamdani, When Victims Become Killers: Colonialism, Nativism, and the Genocide in Rwanda (Princeton, NJ: Princeton University Press, 2001), 82-83.

${ }^{13}$ Scott Peterson, Me Against My Brother: At War in Somalia, Sudan and Rwanda (London: Routledge, 2001), 247, quoted in Alexandra A. Miller, "From the International Criminal Tribunal for Rwanda to the International Criminal Court: Expanding the Definition of Genocide to Include Rape," Penn State Law Review 108, no. 1 (2003), 352.

${ }^{14}$ In February of 2012, Mugesera was deported to Rwanda and charged after his attempts to avoid deportation were denied by a Canadian Federal Court.

${ }^{15}$ Timothy Longman, "Christian Churches and Genocide in Rwanda," in In God's Name: Genocide and Religion in the Twentieth Century, eds. Omer Bartov and Phyllis Mack (New York and Oxford: Berghahn Books, 2001), 153.

${ }^{16}$ Taylor, Sacrifice as Terror, 154.

${ }^{17}$ Diane Marie Amann, “Prosecutor v. Akayesu. Case ICTR-96-4-T,” The American Journal of International Law 93, no. 1 (January 1999), 195-99. This distinction proved problematic for the Rwandan Tribunal because Hutus and Tutsi are not, from an ethnographic perspective, different ethnicities. However, the Tribunal decided that it was enough that the Hutu and Tutsi regarded each other as ethnically different. See Prosecutor v. Jean-Paul Akayesu (Case No. ICTR-964-T) Judgment, paras. 701-2, September 2, 1998.

${ }^{18}$ Anton Blok, “The Narcissism of Minor Differences," European Journal of Social Theory 1, no. 1 (1998), 33-56. This term appears in such essays as the Taboo of Virginity (1917) and Civilization and Its Discontents (1930).

${ }^{19} \mathrm{Ibid} ., 34$. Here, Blok is recounting Sigmund Freud's summary of a study by Ernest Crawley.
} 
and the threat to identity that comes from what is closest...'Social identity lies in difference, and difference is asserted against what is closest, which represents the greatest threat."' 20 Applied to Rwanda, the Hutu architects of the genocide exploited shared Rwandan religious symbols and ideals, often perverting or inverting their multivalent meanings. This tactic reinforced the enmity between the largely homogenous groups of Hutu and Tutsi based on a few but inflammatory (and largely confabulated) dissimilarities.

Although there is no causal link between the Hamitic myth and the 1994 genocide, the myth was certainly a significant and contributing factor in sowing enmity between Hutu and Tutsi that culminated in conditions conducive to genocidal violence.

Moreover, these references built upon a recurrent component of genocide, the dehumanization of fellow humans. The Hutu Power elite vilified Tutsi by likening them to animals and insects, making them unrecognizably human and therefore not one of "us." Hutu propagandists then aligned this vilification with potent and familiar religious rhetoric. For example, Des Forges writes that during an attack, one killer shouted, "You are snakes. Your god does not exist. We will exterminate you," ${ }^{21}$ and during a November 22, 1992 speech delivered to the ruling party, the National Republican Movement for Democracy and Development or Mouvement républicain national pour la démocratie et le dévelopement (MRND), Mugesera proclaimed that "He [Jesus] is God born of God." In the same way, they [Tutsi] are "Inyenzis [cockroaches] born of Inyenzis, who speak for Inyenzis." ${ }^{22}$ Both of these statements juxtapose dehumanizing language next to biblical references - to snakes, which are commonly associated with Satan and the widely accepted belief that Tutsi are cockroaches - creating a mental and moral space that encourages the massacre of the other because they fall outside of the circle of human regard and divine consideration.

Perhaps one of the most charged examples of a message that othered Tutsi by likening them to cockroaches and snakes was not in the form of a speech but in the written word. In Rwanda, Kinyarwanda and French are the two most common languages. Kangura (translated wake others up), a hate-mongering Rwandan magazine published by the ruling Hutu MRND party was founded to oppose the similarly titled magazine, Kanguka (translated wake up), sponsored by the Tutsi-led Rwandan Patriotic Front. The November 1991 issue of Kangura chillingly depicted on its cover a picture of the second president of the First Republic, Grégoire Kayibanda, accompanied by a machete (a common Rwandan farming tool). Kayibanda installed Hutu as the governing ethnicity after the 1959 Wind of Destruction. The picture was accompanied by the words "Tutsi: Race of God!?" and supplemented by a phrase that appears between the images of Kayibanda and the machete: "Which weapons are we going to use to beat the cockroaches for good?" 23 Allan Thompson remarks on the irony of referring to Tutsi as the "race of God," and cites an excerpt from an article that appears on page seven of the issue, contending that the Hutu and Tutsi cannot co-exist because Tutsi are "thieves, they are involved in intrigues, they are wicked, they are killers. And they are people who have grudges just like serpents." ${ }^{24}$ In one fell swoop, the cover appeals to a historical grievance, Christian symbols, and dehumanizing vocabulary, all synergistically harnessed for the purpose of imparting a singular message: the rightful obliteration of the dangerous Tutsi other.

A scene from the documentary film by Nick Andrews, Roger: Genocide Baby, further highlights how appeals to religious concepts, even if not explicitly biblical, reinforce the idea of an other. Miss JoJo, a popular Rwandan recording artist who memorializes the genocide in her music, relays witnessing the shooting of her mother. She indicates that men entered the house and sorted the inhabitants for execution: "Then they started saying 'We want to see all those who have the sin to go this side. And those who don't have the sin to go this side...."'25 Similarly, a twelve-year-old boy

\footnotetext{
${ }^{20}$ Ibid., 38.

${ }^{21}$ Alison Des Forges, Leave None to Tell the Story: Genocide in Rwanda (New York: Human Rights Watch, 1999), 304, accessed May 1, 2012, https://www.hrw.org/report/1999/03/01/leave-none-tell-story/genocide-rwanda.

22 “Translated 1992 speech of Leon Mugesera," Rwanda Gateway, accessed October 10, 2013, http://www.rwandagateway. org/spip.php?article1340.

${ }^{23}$ Allan Thompson, The Media and the Rwandan Genocide (London: Pluto Press, 2007), 335.

${ }^{24}$ Ibid.

${ }^{25}$ Roger: Genocide Baby, directed by Nick Andrews (London: British Broadcasting Corporation, 2011), DVD.
} 
Temoney

who was manning a barrier that was part of a network of roadblocks designed to stop fleeing Tutsi in the Maraba commune, when "asked why the Tutsi should be killed, replied with assurance, 'Because they are evil."' 26 The use of the words "the sin" and "evil" are telling, as they seem to convey that Tutsi are immanently wicked, marred in some deep way that only the religiously inflected words sin and evil can communicate. Tutsi were indelibly marked by transgression, a transgression that, in the view of the Hutu, necessitated their extermination.

\section{Justification}

Religious concepts, some specific to Rwandan colonial mythologies as well as to indigenous cosmologies, provided a framework of meaning for communal genocidal violence and the expectation of the amelioration of social and economic strife. Religious symbols and rituals shaped genocidal thinking by casting the Tutsi other as the embodiment of a threat not only to temporal Hutu survival but as a threat to the divine order itself, providing justifications for the elimination of the Tutsi not only in the secular sense but in the cosmological sense. The symbolism and mythologies that sustained Rwandan religious systems also sustained the mass killing, transforming criminal deeds into a religious obligation of sacrifice. Georg Simmel explicitly connects religion, sacrifice, and obligation when he writes, "as one can consider it as the specific accomplishment of religion that it made people turn their own salvation into an obligation....one can derive from it the right to the most terrible sacrifices - not only self-imposed, but also sacrifices imposed on others." ${ }^{27}$ Three illustrations of religious justifications and frameworks for justifying and sacralizing the genocide include the cosmological notion of imaana and the disorderly flow of imaana in blocked bodies as described by Christopher Taylor; what Jacques Sémelin refers to as the religious new logic that transformed victims into necessary sacrifices, attended by the sacral accoutrements of churches and ritual; and what I contend is the appropriation of religious rhetoric to justify and validate extermination, largely by making biblical references. Let us examine each one in turn.

Not all the religious overtones of the genocide can be attributed to colonial influence. As a review of pre-colonial Rwandan rituals and beliefs of the ancestral religion of Kubandwa indicate, there is an indigenous ontological conviction in Imaana, "a supreme being, and in a more generalized way [imaana refers] to a 'diffuse, fecundating fluid' of celestial origin whose activity upon livestock, land, and people brought fertility and abundance." ${ }^{28}$ Imaana includes a scheme of physical flows and blockages, whereby the human body and geographical space are viewed as conduits of this creative force, which guarantees the life and fecundity of the community. One of the primary "ritual functions of the Rwandan sacred king" is the orderly flow of imaana, not to do so makes the sacred king a "blocked being" or "wild sovereign" who is not an effective "conduit" of the beneficence that passes from sky to earth - to the Rwandan kingdom. ${ }^{29}$ One justification for genocide that is heavily informed by the import of this ontology relates to the restoration of the prosperity that Rwandans enjoyed in the 1980s before the economic crisis that triggered a global plunge in coffee prices in the 1990s. The sacred gravity of this restoration and its connection to the 1994 genocide is only possible and intelligible within the Rwandan cosmological context of imaana and the embodiment of imaana - or the sacred king, to whom President Habyarimana was often compared. President Habyarimana, whose very name translates to "It is God who gives life," was often portrayed as a sacred king in popular news magazines in the 1990s, both in flattering and unflattering depictions and articles. ${ }^{30}$ A cartoon of President Habyarimana portrays him as a closed conduit who recycles all the benefits of imaana within himself and does not allow beneficence to flow to the people by depicting him on all fours and using a spoon, poised under his anus, to eat

\footnotetext{
${ }^{26}$ Des Forges, Leave None, 243.

${ }^{27}$ Georg Simmel, Soziologie [1908] (Berlin: Duncker \& Humbolt, 1983), 405, quoted in Anton Block, “The Narcissism of Minor Differences," European Journal of Social Theory no.1, 1 (1998): 41. Quote translated by Anton Black.

${ }^{28}$ Christopher C. Taylor, "Genocide and the Religious Imaginary in Rwanda," in The Oxford Handbook of Religion and Violence, eds. Mark Juergensmeyer et al. (New York: Oxford University Press, 2013), Ibid., 271-72.

${ }^{29}$ Ibid., 273-76.

${ }^{30}$ Ibid., 275-76.
} 
his own excrement. ${ }^{31}$ Taylor contends, "the cartoon evokes imagery of the inadequate king, the one who blocks celestial flow," ${ }^{32}$ which implies that "Habyarimana must be killed." ${ }^{33}$ The symbolism communicated in the cartoon discloses the "ritual and mythological component" that is "beneath the surface of ideology and the avowed intentions of social actors in the genocide... [and] reveals something about the deeper fears and desires of the génocidaires." ${ }^{34}$ These deeper fears swelled under Habyarimana's regime and focused on Habyarimana as an ineffectual Hutu leader, but after Habyarimana's death, these fears found a new focus - Tutsi as a "credible" collective menace. Taylor further argues that these deeper fears are what galvanized the religious imaginary's commitment to slaughter a perceived Tutsi threat, noting that the composition of this fear was "thoroughly modern" in that it required applying the flow/blockage metaphor typically reserved for individuals [Habyarimana] to an entire group [Tutsi]. Taylor's summation of this reworking of the metaphor is worthy of quoting in full:

[The]...contagion of 'bare life' did not stop with Habyarimana. With his externality made visible [due to his being a 'wild sovereign' and 'blocked conduit'], it was then possible for Hutu extremists to insist on the externality of others, in this case, all Rwandan Tutsi, who were tarred with the accusation that they were 'invaders from Ethiopia.' Reduced to 'bare life,' Tutsi were a reminder that the lingering externalities within the polity threatened its social and moral integrity. If a 'sacred king' could not get rid of them, then the people must do it themselves. Tutsi had become the 'blocked beings,' and they were everywhereneighbors, colleagues, sometimes even wives and mistresses. No pity could be shown. ${ }^{35}$

An additional illustration of a reference to blocked beings is within a context of syncretism between the Rwandan practice of impalement and the centrality of the crucified Christ in Christianity. A cartoon depicting the imagined reinterpretation of the assassination of Melchior Ndadaye, the first President of Burundi to be democratically elected, styles him as an ineffectual conduit as indicated by his anal impalement, yet he is also crucified-a specimen of the synthesis of "specifically Rwandan symbols with deep historical and ontological roots...merged with those that are the more recent product of Christian evangelization." ${ }^{36}$ What Taylor makes clear is that by examining the religious aspects of the circumstances and media leading up to the 1994 genocide, we can more thoroughly appreciate the mindset and actions of the religious imaginary and gain a fuller understanding of the motivations of genocide perpetrators.

Taylor also extends flow/blockage symbolism to the erection of roadblocks designed to trap Tutsi. The excessive number of roadblocks outstripped their pragmatic effectiveness, signaling that their use pointed to some additional purpose beyond their obvious one. Moreover, a religious justification of the genocide also included the ritualized nature of the killing, which permitted the synergy of sacred time and space to render Tutsi as necessary sacrifices in a cosmological battle in order to preserve the sacred community. "Barriers were ritual and liminal spaces where obstructing beings' were to be obstructed in their turn and cast out of the nation. The roadblocks were the space both of ritual and of transgression", ${ }^{37}$ as were the rivers that were congested with the bodies of Tutsi victims being sent back to their ancestral Egyptian home.

A second justification was informed by ritualistic behavior. Sémelin refers to a new logic that religion can sustain in the interest of the practices of the collective for the sake of the "sacred entity," a term that captures how Hutu perpetrators could see themselves as victims in a battle for

\footnotetext{
${ }^{31}$ Ibid., 275-77.

${ }^{32}$ Ibid., 274-78.

${ }^{33}$ Ibid., 277.

${ }^{34}$ Ibid.

${ }^{35}$ Ibid., 278.

${ }^{36}$ Taylor, Sacrifice as Terror, 174.

${ }^{37}$ Christopher C. Taylor, "The Cultural Face of Terror in the Rwandan Genocide of 1994," in Annihilating Difference: The Anthropology of Genocide, ed. Alexander Laban Hinton (Berkeley and Los Angeles: University of California Press, 2002),Taylor, "Cultural Face of Terror," 161.
} 
their own survival:

While institutional religion (through the Christian Church) was no longer...the spiritual guarantor for the prohibition of murder, a new logic was tending to develop: one that put the perpetration of murder at the centre of religion, or rather at the centre of another kind of sacred entity-a sacred entity which, depending on the instance, assigned itself as a common object of veneration, whether race, the nation or ethnicity. This sanctification of the 'elected' majority presupposes the building of a sacrificial altar on which to burn all those designated at that 'other.'... The relationship to violence has thus been completely reversed: murder is no longer a taboo to be observed but becomes, on the contrary, a foundational practice - not of a new religion, but of a different conception of collective transcendence, that draws on instituted religious practices, or even recycles them. ${ }^{38}$

This logic, albeit an apparently self-justifying logic, relies upon familiar religious practices for its validation. The actors and meaning of the genocide become religiously stylized, and events unfold within familiar spaces and rituals. In this light, one of the most appalling features of the genocidethat a vast number of Tutsi were killed in and around churches - is of particular significance and a complex, even contradictory phenomena, as génocidaires simultaneously destroyed and embraced religious symbolism. ${ }^{39}$ "Tabernacles, baptismal fonts, pulpits, vestments, crucifixes, statues, altars, Bibles and prayer books - all the sacred symbols and icons of religion-were slashed and damaged." 40 However, "there are many reports of screaming victims being physically dragged to churches before being killed at the entrances, ${ }^{\prime 41}$ as if to assign sacral, even sacrificial, meaning to the act of killing in front of the church whose very sacred symbols were desecrated. A more explicit ritual practice, one directly informed by Kubandwa, fused genocide with sacramental implications when attackers donned the dress of warriors practicing kubohoza (translated "to help liberate").

The ntore were the elite in the military system that existed before the arrival of the Europeans. Kubandwa is a religion widely practiced in the central lakes region since the sixteenth century. In its rituals, participants sometimes put kaolin, or chalk, on their faces. ${ }^{42}$

When people engaged in kubohoza, they sometimes covered their faces with chalk, wore banana leaves, attacked at the signal of a whistle, marched to a drum and manned barriers along the roads to catch their prey. During the genocide, some assailants did the same things. ${ }^{43}$

The attackers wore leaves. The women wore the leaves on their hips. The men wore them crossed like an " $X$ " across the chest, in the style of intore. They had chalk around the eyes, as if for kubandwa, and they shouted "tuzabatsembatsemba!" [We have come to exterminate!].

Religious rhetoric, connotations, and symbols gesture toward the unthinkable, the unknowable, the unfamiliar, the remarkable, the contradictory, and in doing so renders experiences imbued with religious language and references as familiar, thinkable, unremarkable, and coherent. In

\footnotetext{
${ }^{38}$ Jacques Sémelin, Purify and Destroy (London: Hurst, 2007), 90.

${ }^{39}$ These practices of killing near and in churches and desecrating and embracing religious symbolism defy a definitive or simple explanation. It is the case that killing Tutsi in churches was an economical strategy because the observance of sanctuary guaranteed that perpetrators could quickly locate large numbers of Tutsi in one space with ease, but why was sanctuary ignored in the 1994 conflict and not in prior conflicts? Furthermore, perhaps Hutu destroyed church symbols in recognition of its foreign presence and as an affirmation of indigenous religion or as a signal of the appropriation of the authority of religion for themselves? More simply, perhaps the frenzy of genocide spilled over into wanton acts of destruction, of religious and non-religious objects and buildings alike.

${ }^{40}$ Hugh McCullum, The Angels Have Left Us: The Rwanda Tragedy and the Churches. Risk Book Series (Geneva: WCC Publications, 2004), 76.

${ }^{41}$ Ibid.

${ }^{42}$ Des Forges, Leave None, 312, n. 156 and 157.

${ }^{43}$ Ibid., 47.

${ }^{44}$ Ibid., 304
} 
short, religious language provides a scheme for tolerating and articulating what would otherwise seem exceedingly intolerable or unspeakable.

Third, the Rwandan genocide is replete with examples of Hutu genocide architects situating the extermination of Tutsi within recognizable religious narratives and rhetoric, rhetoric that conscripts divine approval and portrays the genocide as being of ontological proportions. The primary conduits of genocide-inciting propaganda in Rwanda, were radio broadcasts and newspapers, which appealed to divine authority and used biblical references. Des Forges confirms this point with her observation that "propagandists used religion and the church to validate their teachings. Umurava Magazine declared 'It is God who has given Habyarimana the power to direct the country, it is He who will show him the path to follow.' Most propagandists did not go so far, but they did frequently couch their ideas in religious language or refer to passages from the Bible." For example, "Mugesera exhorts his audience to 'rise up...really rise up' in self-defense. He cites the Bible several times and declares that the MRND has a new version of the Biblical adage to turn the other cheek: 'If you are struck once on one cheek, you should strike back twice'"155 and "We must do something ourselves to exterminate this rabble. I tell you in all truth, as it says in the Gospel, 'When you allow a serpent biting you to remain attached to you with your agreement, you are the one who will suffer."'46 An unabashed, and most likely well known, propagandist appeal to the Bible is the infamous publication of the Hutu 10 Commandments, widely circulated in December 1990, ordering Hutu to fulfill their moral obligation to utterly destroy societally unfit Tutsi-coded though clearly understood, radio broadcasters urged Hutu to "do your work" and "cut the tall trees." ${ }^{47}$ Moreover, propagandists promoted the genocide as meeting with divine approval. "Sindikubwabo finished a speech by assuring his listeners that God would help them in confronting the 'enemy.' RTLM announcer Bemeriki maintained that the Virgin Mary, said to appear from time to time at Kibeho church, had declared that 'we will have the victory'. In the same vein, the announcer Habimana said of the Tutsi, 'Even God himself has dropped them."'48 In addition, a radio announcer jubilantly blared, "Let us rejoice friends. The cockroaches have been exterminated. Let us rejoice friends. God is never wrong." ${ }^{49}$ Des Forges succinctly pinpoints the effectiveness of the propagandists" religious rhetoric and biblical appeals when she avers that "in a country where 90 percent of the people called themselves Christian and 62 percent were Catholic, ${ }^{50}$ these references to religion helped make the teachings of fear and hate more acceptable." ${ }^{51}$

\section{Authorization}

Des Forges believes that "many Rwandans say that they killed because authorities told them to kill ... reflect[ing] less a national predisposition to obey orders, as is sometimes said, than a recognition that the 'moral authority' of the state swayed them to commit crimes that would otherwise have been unthinkable." ${ }^{22}$ Contra Des Forges, many scholars do not weigh these two points against each other as much as they discuss them as informing each other. Within the context of the Rwandan genocide from this latter perspective, the moral authority of the state was buttressed by the teachings of obedience by religious authorities who endorsed the political power structure. As Des Forges herself writes, "Far from condemning the attempt to exterminate the Tutsi, Archbishop Augustin Nshamihigo and Bishop Jonathan Ruhumuliza of the Anglican Church acted as spokesmen for

\footnotetext{
${ }^{45}$ Ibid., 69.

${ }^{46}$ Antonio A. Cassese et al., eds., International Criminal Law: Cases and Commentary (New York: Oxford University Press, 2011), 415, para. 17.

${ }^{47}$ Philip Gourevitch, We Wish to Inform You that Tomorrow We Will be Killed with Our Families: Stories from Rwanda (New York: Farrar, Straus \& Giroux, 1998), Gourevitch, We Wish to Inform You, 17.

${ }^{48}$ Des Forges, Leave None, 189.

${ }^{49}$ Andrews, Roger: Genocide Baby.

${ }^{50}$ A 1991 census conducted by the Government of Rwanda indicates that 89.8 percent of the population claimed Christian Church membership: 62.6 Catholic, 18.8 percent Protestant, and 8.4 percent Seventh Day Adventist. See Longman, "Christian Churches," 149, n. 23.

${ }^{51}$ Des Forges, Leave None, 61.

${ }^{52}$ Ibid., 14
} 
the genocidal government at a press conference in Nairobi," 53 and many who did not actively condone genocide at least tacitly did so by remaining silent. Churches were sites for the planning and commission of genocides, clergy sacralized violence through ritual and religious mythologies, and the most explicit authorization of genocide by church authorities was active participation, killing, or aiding in the direct killing of victims. According to Mamdani, the church connections of the radical Hutu movement are

...the clue as to why the violence was marked by greater fury in the Church than in any other institution in Rwandan society. The Church was the original ethnographer of Rwanda. It was the original author of the Hamitic hypothesis..., without the church, there would have been no 'racial' census in Rwanda. ${ }^{54}$

It seems that Mamdani is contending that genocide perpetrators were bringing the eradication of Tutsi full circle by killing the majority of Tutsi in the very places that nurtured the racial ideologies that would eventually culminate in their demise.

The ICTR indicted several members of the clergy for their participation in genocide. Some of the most notorious of the defendants were Father Wenceslas Munyeshyaka, who allegedly turned over Tutsi refugees to Hutu militia and Rwandan armed forces to be killed and raped; he was convicted in absentia in 2006, and the case was referred to a French Court, but the case was dismissed in October 2015. ${ }^{55}$ Father Athanase Seromba was convicted in December 2006 for allowing his church to be bulldozed with 2,000 Tutsi refugees inside. ${ }^{56}$ Elizaphan Ntakirutimana (deceased) was a pastor and president of the West Rwanda Association of the Seventh Day Adventist Church based in the Mugonero Complex, Gishyita commune, Kibuye prefecture. His son, Dr. Gérard Ntakirutimana, was a medical doctor at the Seventh Day Adventist's hospital at Mugonero Complex, Gishyita commune. Pastor Ntakirutimana is the person whom several pastors addressed in a letter containing the words that would be used as the title of an award-winning book by Philip Gourvetich, We wish to inform you that tomorrow we will be killed with our families: Stories from Rwanda. Pastor Ntakirutimana's response to this appeal was "Nothing can be done." 57 He was also the first clergyman to be found guilty by an international tribunal. Both men were found guilty of leading Hutu attackers to Mugonero Adventist church and to a hospital complex in Kibuye where unarmed Tutsi were seeking refuge.

In 2001, a Belgian court ${ }^{58}$ found two other religious figures, Sister Gertrude (née Consolata Mukangano) and Sister Maria Kisito (nee Julienne Mukabutera), Benedictine nuns, guilty of genocide for collaborating with Hutu militia by driving out Tutsi in the Sovu convent in Butare, Rwanda, who were seeking safety, to a Hutu militia and their certain death. More recently, in 2010, Emmanuel Rukundo, a military chaplain for the Rwandan army, was convicted of genocide for killing a Tutsi woman, abducting and causing bodily harm to several women, and sexually assaulting a woman..$^{59}$ These indictments are profound because of what seems to be a literal inversion of the expectations society holds of clergy and of general church conduct. Given that clergy are typically seen as moral paragons and that churches are, literally, sanctuaries, what is surprising and disturbing, is that many clergy were directly involved in killing and raping victims Scores of Tutsi lost their lives within and immediately outside church walls and mission compounds; the villages

\footnotetext{
${ }^{53}$ Ibid., 189.

${ }^{54}$ Mamdani, When Victims Become Killers, 232.

${ }^{55}$ James Karuhanga, “Govt slams France's dismissal of Munyeshyaka Genocide case," The New Times, October 7, 2015, accessed May 18, 2016, http://www.newtimes.co.rw/section/article/2015-10-07/193276/.

${ }^{56}$ Marc Lacey, "Rwandan Priest Sentenced to 15 Years for Allowing Deaths of Tutsi in Church," The New York Times, December 14, 2006, accessed May 18, 2016, http://www.nytimes.com/2006/12/14/world/africa/14rwanda.html? r=0 .

${ }^{57}$ Gourvetich, We Wish to Inform You, 41.

${ }^{58}$ Given the role that Belgian colonization played in widening the divisions among Hutu and Tutsi in Rwanda by issuing identity cards, it seems ironic that a Belgian court should find two Rwandans guilty of a crime that was in large part made possible by Belgian imperial policies.

${ }^{59}$ Emmanuel Rukundo v. The Prosecutor, Judgment, October 20, 2010, ICTR-2001-70-A, October 20, 2010.
} 
and cities that were sites of the deadliest massacres were Nyamata, Musha, Ntarama, Nyarubuye, Cyahinda, Nyange, Saint Famille, and Karubamba. ${ }^{60}$ It is not unreasonable to expect that Rwandan nuns, pastors, and chaplains should have vehemently objected to the slaughtering of innocent men, women, and children. Instead, as Alison Des Forges keenly observes, "church authorities left the way clear for officials, politicians, and propagandists to assert that the slaughter actually met with God's favor," ${ }^{61}$ - and indeed, believed to be sanctioned by divine fiat. Only referred to as "The Witness" in an ICTR transcript, a victim testified that "later on while I was hiding I heard them [a group of attackers under the Pastor's direction] saying that Pastor Ntakirutimana had said that God had ordered that the Tutsi should be killed and exterminated." 62

Longman sheds light on why he believes this moral inversion was possible in Rwanda. "Christians could kill without obvious qualms of conscience, even in the church, because Christianity as they had always known it had been a religion defined by struggles for power, and ethnicity had always been at the base of those struggles." ${ }^{63}$ Longman provides powerful imagery to support his point when he writes,

...while churches were not the chief organizers of the Rwandan genocide, their long practice of teaching obedience to authority and of engaging in ethnic politics made it possible for Rwandans to ignore the principle of sanctuary and participate in the killing of Tutsi without feeling that their actions were in conflict with church teachings. In fact, the organizers of the death squads in many local communities included not only prominent lay church leaders but sometimes priests, pastors. Catholic brothers, catechists, and other church employees, and the fact that death squads attended mass before going out to kill or that killers paused during the massacres to pray at the altar suggests that people felt their work was consistent with church teachings. Far from being mere passive bystanders, Christian churches provided essential support for the slaughter. ${ }^{64}$

As shocking as these events were, and although the relationship between religion and genocide defies an easy explanation, Longman's contextualization helps us better understand how these acts were possible. Namely, how is it that so many perpetrators perceived no inconsistencies between killing and church teachings? However, Longman's point regarding obedience to authority also provides some insight into how Hutu killed knowing that their actions were inconsistent with church teachings: "Deep down we knew that Christ was not on our side in this situation, but since he was not saying anything through the priests' mouths, that suited us." ${ }^{65}$ In other words, many Hutu perpetrators were viscerally aware that their behavior was immoral, but this awareness was undercut by a longstanding, cultural habituation to obey clerical authorities who, in effect, condoned the killing of Tutsi through their lack of condemnation. Although many Hutu and Tutsi clergy forfeited their lives to protect Tutsi refugees, out of fear of deadly retaliation, many clergy, especially Tutsi clergy, were unable to exercise their ecclesiastical authority and mount a successful counter campaign that effectively challenged the dominant genocidal ideology promulgated by Hutu clergy. Collectively, it appears that the immediate influence of Hutu clergy, longstanding practice of conditioning Rwandans to obey authority, and cooperative relationship between churches and the state, severely undermined the overall ability of churches to effectively condemn the killings. For example, another confessed génocidaire, Ignace, stated,

God kept silent, and the churches stank from abandoned bodies. Religion could not find its

\footnotetext{
${ }^{60}$ René Lemarchand, "The Rwandan Genocide," in Century of Genocide: Eyewitness Accounts \& Critical Views, eds. Samuel Totten, William S. Parsons, and Israel W. Charny (New York \& London: Garland Publishing, Inc., 1997), 416.

${ }^{61}$ Timothy Longman, "Church Politics and the Genocide in Rwanda," Journal of Religion in Africa 31, no. 2 (2001), 164.

${ }^{62}$ The Prosecutor v. Elizaphan Ntakirutimana Gérard Ntakirutimana, Judgment, December 13, 2004, ICTR-96-10-T / ICTR-9617-T, para. 276.

${ }^{63}$ Longman, "Church Politics," 164.

${ }^{64}$ Ibid., 166-67.

${ }^{65}$ Jean Hatzfeld, Machete Season: The Killers in Rwanda Speak, trans. Linda Coverdale (New York: Farrar, Straus, and Giroux, 2003), 145.
} 
place in our activities. For a little while, we were no longer ordinary Christians... We had to obey our leaders - and God only afterward, very long afterward, to make confession and penance. When the job was done. ${ }^{66}$

A case in point is that prior to the 1994 genocide Archbishop Nsengiyumva severed his official tie to Habyarimana's ruling party, the MRND, but he still remained friends with members of the regime and later arranged a papal visit to Rwanda - the latter was "a clear sign of a 'blessing' of the Habyarimana regime in the eyes of the population." ${ }^{67}$ The 1990 Le Christ, notre unité (In Christ our unity) - a pastoral letter among a series of letters released by Catholic bishops before, during, and after the genocide - rebuked ethnic enmity and various evils, but the archbishop's relationship with the regime proved disastrous and undermined the bishops' condemnations, as "the church had lost all its credibility in political matters." ${ }^{68}$ Whether church teachings were consistent or inconsistent with killing, the tendency to obey authority prevailed.

\section{Genocide, Religion, and Sexual Violence}

Given the excess of genocide, perhaps it is not surprising that totalizing religious language and the ultimate violation of sexual violence so effectively potentiate genocidal ideology and behavior. Within the context of genocide, sexual violence and religion combine when perpetrators target and intimately violate the human body as a means of physically, symbolically, and even cosmologically, reimaging and reconstructing the social and political order by destroying a perceived enemy. These forms of destruction are not random: perpetrators act within a culture-specific logic that religious language, mythoi and rituals provide, and génocidaires contort and exploit religious texts and imagery as a basis for this language.

Sexual violence and religion are both largely understudied in genocide literature because, until recently, scholars and legalists largely treated sexual violence as ancillary to warfare (rather than as a weapon of war). Similarly, scholars marginalize religion in genocide because religion is rarely the principal point of departure for genocide, as opposed to ethnic tensions or political power grabs. Nonetheless, sexual violence and religion are both effective conduits of the power of politics and other social struggles, as they can foment, potentiate, and actualize genocidal action. Therefore, their study can deepen and nuance our understanding of the dynamics of genocide. Sexual violence is one of the most effective and heinous demonstrations of power over another and strategies for disrupting entire communities. Combined with religion - a meaning-making system that includes transcendent referents and pertains to matters of ultimacy - sexual violence and religion form a potent foundation for violent action. By examining the intersections of genocide, religion, and sexual violence, the goal is to bring the complex components of genocide into greater relief. Acts of sexual violence and the perversion of religion in genocide are tantamount to bringing about a social and spiritual death that "mock[s] the possibility of any moral life," and they severely cripple a community's ability to reconstitute itself. ${ }^{69}$

I contend that religion has both a distal (or indirect) and proximate (or direct) relationship to physical acts of sexual violence. The distal influence of religion indirectly contributes to the perpetration of sexual violence by contributing to conditions that are conducive to sexual violence and rape, but this influence is so diffuse that it is difficult to pinpoint religious influence as a primary cause or as reflecting any readily recognizable and particular religions belief, practice, or ritual. Examples of this diffuse influence include the patriarchal beliefs and practices of religious traditions that devalue the personhood of women yet value women as property. This longstanding devaluation and objectification of women during peacetime makes women more susceptible to sexual violence during wartime and particularly during genocides because of the biological and

\footnotetext{
${ }^{66}$ Ibid., 142.

${ }^{67}$ Jerald D. Gort, Hendrick M. Vroom, and Henry Jansen, eds., Religion, Conflict and Reconciliation: Multifaith Ideals and Realities (Amsterdam: Rodopi B.V., 2002), 332.

${ }^{69}$ Robert W. Smith, "Genocide and the Politics of Rape," in Genocide Matters: Ongoing Issues and Emerging Perspectives, eds. Joyce Apsel and Ernesto Verdeja (New York: Routledge, 2013), 90.
} 
cultural role women play in perpetuating ethnic bloodlines. Functionally, religion distally or indirectly plays the same role in laying the groundwork for sexual violence as it does in genocidethrough othering, justification, and authorization.

The actions and religious rhetoric of perpetrators and religious officials contribute to the othering of the enemy, even to the extent of considering them evil and falling outside the circle of moral regard. This contributes to the dehumanization of members of the enemy group, making enemies an acceptable object of sexual violence. Moreover, religious othering and rape mutually reinforce each other in the process of dehumanization. The force of religious rhetoric paints an other as so radically different that they are susceptible to acts of violence, including rape, yet rape can also so dehumanize an enemy that religiously inflected violence is not morally problematic. Religious justifications, per the just war tradition, have a tendency of leading to total violence, and one of, if not the most severe type, of violence a person can suffer is sexual violation. Religious mythologies are able to justify the victimization of the enemy group because, as one scholar argues, "religion is the only other entity [than state authority] that can give moral sanction for violence."70 These mythologies can recast or reshape reality in a manner that transforms the profane into the sacred, providing the moral and psychological space for religiously inflected sexual violence, which sustains and maximizes the destruction of genocide. The authorization of sexual violence is realized through the moral authority of religious officials and religious institutions that support genocide or stand mute before it-in essence providing a blanket sanctioning of the government's aims and methods of genocide through an act of omission. This tacit sanctioning permits behavior that is otherwise criminal, such as murder and rape, and indirectly (or distally) endorses and sustains genocide. In addition, and in the aftermath of genocide, the actions of religious officials actualize the aims of perpetrators by upholding and reinforcing the patriarchal and cultural mores surrounding the chastity of women and patrilineal descent-rendering a raped woman unmarriageable and a forcibly impregnated woman the mother of a child of the enemy group, respectively. In both cases, the cultural practices and religious mores of the victim group are crucial to the effectuation of the perpetrator group's strategy to eliminate the target group.

Contrast this distal use of religion to its proximate or direct influence, where the ritual and pattern of sexual cruelty is specifically evocative of the religious beliefs and practices of the perpetrator and/or victim group. For example, perpetrators can use religious rhetoric while sexually assaulting their victims, force victims to break religious taboos in order to intensity the shame of their experience, or sexually violate victims in a ritualistic fashion after their deaths. The proximate influence of religion to acts of sexual violence, although readily recognizable as religiously inflected, is a secondary cause in the sense that acts of sexual violence that explicitly reflect religious overtones are only possible after the more diffuse and distal or indirect influence of religion and sexual violence has been established. The distinction between the distal and proximate influences of religion on acts of sexual violence is instructive for prevention strategies because it allowsustorefocustheattention, away from theexplicit(or proximate)instancesof religiouslyinflected acts of sexual violence that occur during genocide - which is symptomatic of the primary cause and, therefore, a secondary cause - and toward the pernicious and diffuse influence of religion on sexual violence (distal) prior to and after genocide. Addressing the primary and less visible connection between religion and acts of sexual violence, in the forms of the negative influence of systemic patriarchy on the personhood of women, greatly decreases thelikelihood of religiously inflected acts of sexual violence against women, a secondary cause, during genocide. The best strategy for dismantling the connection among religion, sexual violence, and genocide is for religious leaders and the faithful to actively resist and subvert the patriarchal treatment of women within their own communities as well as the wider secular community in times of war but particularly during times of peace.

\section{The Distal and Proximate Influence of Religion on Sexual Violence in Rwanda Guided by the Typologies}

Tutsi women and girls, as child bearers and sexual objects, were primarily targeted for sexual

\footnotetext{
${ }^{70}$ Mark Juergensmeyer, Global Rebellion: Religious Challenges to the Secular State, from Christian Militants to al Qaeda (Berkeley and Los Angeles: University of California Press, 2008), 255.
} 
violence, but it should be noted that men and boys were sexually violated as well. As dictated by the concept of imaana, Tutsi were characterized as blocked beings who endangered the welfare of the nation. Torture techniques and methods of killing - such as the oblation of sexual organs - was a bodily inscription of the imagined counter-fertility and flow of Tutsi. Torturers reportedly forced Tutsi to commit incest, emasculated men as well as boys of non-reproductive age, and cut off women's breasts - assaults on the reproductive capacities of their victims and transforming them into blocked beings. ${ }^{71}$

\section{Othering}

An exemplification of the distal relationship among religion, genocide, and sexual violence is the colonial Hamitic hypothesis, the focal myth that sustained Tutsi otherness or their status as alien settlers of Rwanda and superior to Hutu. Moreover, many religious traditions are patriarchal and characterize women within their own faith communities as well as recognize in other faith communities the status of women as inferior to men. "Violence is... embedded in social structures, including those of religion. When religious language is used to justify... patriarchal structures of oppression, which are inherently violent because they violate women's human dignity, the circle is complete."72 The circle is complete, here, seems to refer to the formidable and mutually reinforcing synergy between earthly and theological justifications for the subjugation of women, which makes the violence of patriarchy extraordinarily difficult to dismantle because is presents such patriarchy as the given state of our lives and spiritual realities. A distal conceptualization of the influence of religion on genocide offers a translation of the aforementioned metaphorical violence of violating women's human dignity into physical violence during genocides by arguing that patriarchal violence manifests itself under the acute conditions of warfare, which exacerbates pre-conflict societal tensions and inequalities. Imagining the enemy as not just a physical threat but as a cosmological or theological one creates a space for extreme violence for the sake of defending ultimate aims. As an other, victims are not human, and sexual violence further dehumanizes the victim. However, even if victims retain their humanity, their otherness forfeits their right to live or to be safe from harm.

Patriarchal structures in religion view women as subordinate to men, as transactional property, and as morally and spiritually problematic-making females who are members of the enemy group particularly vulnerable to abuse. Taylor indicates how feminist scholarship, such as that by Martha Reineke, enriches the account of the tendency to abuse women in patriarchal societies when he writes, "feminist scholars influenced by psychoanalysis have shown that a propensity exists on the part of some patriarchal social systems to seize upon women as sacrificial victims."73 Taylor continues and highlights the additional characterization of women as people who straddle cultures due to their reproductive capacities, and as a result are particular targets of violence, when he writes, "they [feminist scholars] trace this proclivity to [sacrifice women to] the fact that women are often socially situated at the limen between groups. Perceived as cultural gatekeepers, women can be dangerous in the manner of 'liminal' beings." ${ }^{74}$

The ramifications of patriarchy on genocide were explicitly referenced in Prosecutor $v$. Akayesu. The ICTR chamber found:

In patriarchal societies, where membership of a group is determined by the identity of the father, an example of a measure intended to prevent births within a group is the case where, during rape, a woman of the said group is deliberately impregnated by a man of another group, with the intent to have her give birth to a child who will consequently not belong to its mother's group. ${ }^{75}$

\footnotetext{
${ }^{71}$ Ibid., 140.

${ }^{72}$ Susan Rakoczy, "Religion and Violence: The Suffering of Women," Agenda 61 (2004), 29-35

${ }^{73}$ Christopher C. Taylor, "A Gendered Genocide: Tutsi Women and Hutu Extremists in the 1994 Rwandan Genocide," PoLAR 22, no. 1 (1999): 43.

${ }^{74}$ Ibid. Here, Taylor is citing Douglas 1966 and Turner 1973.

${ }^{75}$ Prosecutor v. Akayesu, Judgment, September 2, 1998, ICTR-96-4-T, para. 507.
} 
These patriarchal sentiments culminated into primarily valuing women for their chastity and roles as wives and mothers. In addition, the Hamitic myth also distally influenced sexual violence:

[T]hough less overtly stated, extremists aimed at reclaiming the lost ground of patriarchy and re-asserting a male dominance that had probably never existed in Rwanda's actual history. Tutsi women were pivotal enemies in the extremists' struggle to reclaim both patriarchy and the Hutu Revolution, because in many respects they were socially positioned at the permeable boundary between the two ethnic groups [in their capacity to produce progeny that were either Tutsi or Hutu as determined by the ethnicity of the father] ${ }^{76}$

Taylor ably argues that genocide in Rwanda cannot be properly understood without examining the "gender issues [that] interacted with ethnic ones in complex ways involving the demarcation of social boundaries and local notions of racial purity"; the destruction of Tutsi women was not only physical but symbolic, as Tutsi women, even prior to the genocide, were objects of sexual ambivalence. ${ }^{77}$ To Hutu men, Tutsi women were more desirable than Hutu women (per the Hamitic myth and the practice of Europeans nearly always coupling with Tutsi rather than Hutu women). Due to this intimate contact between Tutsi women and European men, Rwandans believed that Tutsi women participated in abhorrent "non-procreative and therefore immoral" sexual behavior. ${ }^{78}$ Leading up to the genocide, Hutu extremists seized upon this perception to demonize the counterfertile sexual practices of Tutsi women-primarily in the form of explicit cartoons depicting Tutsi women engaging in group sex, anal penetration, and oral sex with Europeans-much to the disgust of most Rwandans. "Such value judgments," Taylor writes, "may reflect Rwandan acculturation to the sexual norms promulgated by the Catholic Church, but by now they have been well internalized." 79 The violence Tutsi women suffered was an attempt by Hutu men to "purge" this ambivalence in sexually symbolic ways, and this may partially explain why the rapes of Tutus women were particularly brutal. ${ }^{80}$ Women were just as likely to die from the mortal injures of rape as from the blow of a machete.

\section{Justification}

The fact that most victims died immediately or nearly immediately after their assaults, points to a motive other than creating conditions designed to make rebuilding a Tutsi community difficult. As one rape victim testified, "these rapes were designed to humiliate us," a humiliation that nearly always preceded death. ${ }^{81}$ The notion of blocked beings as circumscribed by the cosmological belief in imaana directly informed ritualistic acts of sexual violence. Torture techniques and methods of killing-such as the ablation of sexual organs-were a bodily inscription of the imagined counter-fertility and flow of Tutsi. Torturers reportedly emasculated men as well as boys of nonreproductive age and cut off women's breasts-assaults on the reproductive capacities of Tutsi, which supposedly transformed them into blocked beings. ${ }^{82}$

Genocide perpetrators also forced Tutsi to commit incest in the full view of other family members, and one court witness testified, "I... found a body, ... the legs were apart and the body of her child... was placed on her genitals, as if she was being forced to have sexual intercourse with the mother." ${ }^{83}$ In the aftermath of the genocide, in the town of Nyamata, the body of a woman was discovered in a church with a spear lodged through her vagina that exited her chest. ${ }^{84}$ The fact that

\footnotetext{
${ }^{76}$ Ibid.

77 Taylor, Sacrifice as Terror, 174.

${ }^{78}$ Taylor, "Gendered Genocide," 48.

${ }^{79}$ Ibid.

${ }^{80}$ Ibid.

${ }^{81}$ Christopher W. Mullins, "He Would Kill Me With His Penis": Genocidal Rape in Rwanda as a State Crime," Critical Criminology 17 (2009), 25.

82 Taylor, Sacrifice as Terror, 140.

${ }^{83}$ Mullins, "Kill Me," 25.

${ }^{84}$ Carol Rittner, John K. Roth, and Wendy Whitworth, eds., Genocide in Rwanda: Complicity of the Churches? (St. Paul:
} 
she was violated in a church only heightened the indignity of the act, since until that time Rwandans reliably observed a policy of sanctuary during conflicts. Moreover, as supported by an abundance of ICTR testimonies, ablation, impalement, as well as vaginally and anally assaulting Tutsi victims with sticks, were widespread practices during the genocide. A member of the Interhawame relayed, "I saw these two people rape a girl... I saw them rape her and after that they used a spear to pierce her and they also pierced her sexual organs... I saw [them] cut off [her] breast ... after cutting the girl's breast off he [Kajelie] sucked it." 85

As senseless as these barbarous acts may appear, they were committed within the logic of the bountiful flow of imaana, which was either redirected, as in the case of incest "where blood and semen ... flow backward upon one another in a closed circuit," 86 or blocked, as in the case of the removal of sexual organs and impalement. The counter-fertility of blocked beings, albeit an indigenous Rwandan cosmological logic, was reinforced by the sexual norms of non-native colonial Christianity. Taylor's analysis offers us a nuanced analysis of Hutu attitudes and sexually inflected genocidal behavior rounds out other scholarly observations of the genocide that do not closely attend to Rwanda's religious practices and cosmological framework. Case in point, Elisa von Joeden-Forgey, in her work on the gendered aspects of genocides, argues that genocidal rapists exploit social context and symbols to maximize damage in going "beyond compromising the physical and psychological ability of women and girls to carry children. It seems to puncture - to wound - that invisible space inside a woman's body, the source of the group in the first place." ${ }^{87}$ Could that be the message transmitted by the perpetrators' use of sharpened sticks to rape and kill Tutsi women during the Rwandan Genocide in 1994?" Perhaps, but impalement may have been operant on another level that is only apparent by attending to a more culture-specific religious worldview, such as that of the cosmological view of imaana and blocked beings. ${ }^{88}$ Without this data, a crucial local component of the message that von Joeden-Forgey speculates rapists transmitted to their victim group in public acts of rape during the Rwandan genocide escapes scrutiny.

\section{Authorization}

Neither church officials nor official statements from church bodies sufficiently denounced genocidal rape during or after the genocide, illustrating the distal impact of religion on sexual violence (as opposed to proximate) because these were acts of omission as opposed to commission. A failure to consistently and publicly condemn violence against women cultivates a culture of impunity and tacitly authorizes violence and sexual violence against others, especially given that many ICTR witnesses claimed that church authorities failed to stop, orchestrated, or participated in the sexual victimization of Tutsi. Moreover, organized churches did not leverage their authority to reduce the stigma of raped survivors or to alleviate the social and financial burden endured by rape victims and their children. ${ }^{89}$ The relationship between authorization and genocidal rape as intended to interfere with the perpetuation of ethnic bloodlines is a curious one.

The stigmatization of rape survivors is also distally related to authoritative religious beliefs and doctrine: for example, patriarchal beliefs about female chastity and the Catholic Church's stance on abortion destroyed the potential of women in Rwanda to become wives and mothers and led many of the few surviving women to attempt to abort their own fetuses or commit infanticide. Although the ICTR recognized the practice of forced impregnation during the Rwandan genocide, the repercussions of genocidal rape as a means of preventing Tutsi from perpetuating their bloodline was not a foundational aim of génocidaires. Hutu extremists primarily aimed to physically destroy

\footnotetext{
Paragon House, 2004), 194.

${ }^{85}$ Mullins, “Kill Me," 25.

${ }^{86}$ Taylor, Sacrifice as Terror, 141.

${ }^{87}$ Elisa von Joeden-Forgey, "Gender and the Future of Genocide Studies and Prevention," Genocide Studies and Prevention 7, no.1 (2012), 93.

${ }^{88}$ Taylor, Sacrifice as Terror, 273-76.

${ }^{89}$ Children orphaned during the genocide, but not children born of genocidal rape, are eligible for government financial and social assistance.
} 
Tutsi by killing them outright, not exploiting and depending on the effects of genocidal rape to thin or displace the Tutsi population.

As the nexuses demonstrate, religious rhetoric, belief and practice-as promulgated by institutionalized religion and religious individuals and coupled with the aims and organization of the state apparatus - perniciously prepared the popular imagination for genocide by building a reality where mass killing was thinkable and necessary. This process inverted moral values, or in a Hegelian sense, held competing ideas in tension, resulting in the authorization of behavior that would otherwise be criminal in the name of survival-both temporally and spiritually. This dual capacity is a defining feature of religious belief, which makes religion particularly adept at tolerating contentious and even contradictory ideas. Echoing the language of Rudolf Otto, R. Scott Appleby and others refer to this capacity as the "ambivalence of the sacred," ${ }^{90}$ or the constructive and destructive potential of religion. Mythologies and rituals, by appealing to the potency of religious symbols and tropes, provide the sacred space and means required to sustain and justify genocidal action against a perceived ontological other by situating the genocide in a larger, recognizable, religious drama (a drama that both perpetrators and victims often unreflectively accept). Furthermore, the authorization of genocide by churches and prominent religious figures drew its force from a history of obedience to authority that intimated divine approval and Church sanctification.

Rather than being a haven, the sacred space of church became an altar of sacrifice; rather than acting as a bulwark against violence, religious belief and practice became the center (literally and figuratively) of violence; many parochial figures encouraged rather than intervened in the killings; and Christ-like obedience was transformed into sacrificial killing. The events of genocide that appear to be so extraordinarily inconsistent with generally accepted religious norms are possible because of the capacity of myths to hold contradictory ideas in tension with one another, or to even revise ideas and apprehensions in accordance with religious belief-as explained by Lévi-Strauss. To wit, the logic of religion is analogous to the logic of genocide in that both are closed systems that are not easily susceptible to external critique but must simultaneously establish cogency among conflicting ideas on terms dictated by the system in order for the system to sustain itself. For example, mass killing is considered abominable and in conflict with most religious convictions and generally agreed-upon moral norms, but this conflict can be endured for the sake of defending the cosmological order or ensuring the survival of a threatened group, respectively - thus, the system remains intact. For instance, the seeming congruence of sexual violence and ritual incorporates rape into a web of religious meaning that minimizes cognitive dissonance and sanctifies acts that are otherwise criminal. As Burns reminds us, "it is an odd truth that when faced with circumstances that contradict our constructed meaning systems, we are more likely to change our perceptions of the events than to change our beliefs. Religious systems are remarkably stable in the face of contradictory information." ${ }^{\prime 1}$

\section{The Future of Genocide Studies}

As for possible avenues of the future study of genocide, many of these avenues are implicit in this study. One is that the religious myths, beliefs, and practices of religious traditions as well as the religious rhetoric that perpetrators use to trade on the authority of these traditions, should all be a greater part of genocide studies discourse. Such a strategy would add to the strands of inquiry dedicated to explaining and understanding genocide by providing, in Geertizan terminology, a thick description of local culture that includes how religious practice and belief inform a community's worldview - a worldview that pre-exists and persists during genocides and informs the particular logic of genocidal mentalities and behavior.

Another recommendation is to devote more study to the perspective of genocide perpetrators and the profiles of religious actors who engage in rescue and resistance behavior. ${ }^{92}$ Studying what

\footnotetext{
${ }^{90}$ See Appleby, The Ambivalence of the Sacred: Religion, Violence, and Reconciliation.

${ }^{91}$ Charlene Burns, More Moral than God: Taking Responsibility for Religious Violence (Lanham: Rowman \& Littlefield Publishers Inc., 2008), 5.

${ }_{92}$ There are a multitude of stories of heroism by rescuers and of resistance by victims during the Holocaust; however,
} 
génocidaires believe motivates their actions, religious or otherwise, can yield invaluable insights into genocide perpetration. This is not to say that all perpetrators of genocide are singularly motivated or that a perpetrator's motivation might not be multifaceted and change during the course of a genocide.${ }^{93}$ Moreover, early warning systems designed to detect genocide triggers may also benefit from studies of sexual violence and religion. For example, Taylor's observation that after the 1990 RPF invasion of Rwanda, in the year and months leading up to the 1994 genocide, rapes and other crimes dramatically increased..$^{94}$ In addition, the publication of sexually violent extremist literature also increased, ${ }^{95}$ these trends, in conjunction with other conditions such as economic collapse, can foreshadow genocidal violence.

A tandem approach to studying the perspective of génocidaires, one not explicitly addressed in this essay, is to increase the examination of the psychological and social profiles of individuals who engage in rescue behavior in order to isolate the variables that make it likely that a person will resist genocidal ideology and actions. Some research, such as that of Ervin Staub, attempts to outline factors in one's childrearing and background experiences that foster altruistic behavior, and still other research, by the likes of Julius Landwirth, ask whether rescue behavior can be taught or not. ${ }^{96}$ Although rare, members of faith communities have engaged in rescue behavior. Analogous, to Staub and Landwirth's work, I believe that studying the training and experiences of religious figures who have engaged in altruistic behavior during a genocide will allow us to identify qualities and strategies that can inform parochial education. This approach may also increase the likelihood of members of religious communities resisting genocide and rescuing victims or even engaging in a kind of community building that makes it difficult for genocidal ideology to gain traction among the faithful and wider citizenry. As genocide research continues to flourish, religious tensions and antagonisms should be one of many features of genocide worthy of investigation, alongside other commonly explored factors such as economic crisis, political tensions, and competition for resources. Indeed, the nexus of genocide and religion is complex, but it is as necessary to understand this dynamic as it is difficult to research. Religion and religious studies are fruitful avenues for genocide study not only in identifying how genocides are legitimated and potentiated, but also in how genocides can be prevented and mitigated.

Last, this investigation is of one particular genocide, but there is value in comparing genocides in order to identify not only their differences but also their similarities. The result then is not an identification of the pattern of genocide but rather a pattern of genocide, patterns that not only act as points of departure for comparing similar cases but also expose the limitations of comparison in highlighting where and how similarities break down. An element of this break down is what fuels a recent criticism of genocide research - the failure to research cases of conflict that exemplify a genocidal pattern but do not result in genocide. ${ }^{97}$ This consideration squarely affects efforts to effectively forecast genocide. Moreover, definitional disagreements about genocide, the

much less scholarship exists on individual and group rescue behavior of more recent genocides (such as in Bosnia, Rwanda, and the Sudan), and less literature still that specifically focuses on the psychological and social factors that encourage rescue behavior. For recent, book-length treatments of the dynamics of rescue behavior, see Steven K. Baum, The Psychology of Genocide: Perpetrators, Bystanders, and Rescuers (New York: Cambridge University Press, 2008) and Andrew Michael Flescher, Heroes, Saints, and Ordinary Morality (Washington, DC: Georgetown University Press, 2003).

${ }^{93}$ Evgeny Finkel and Scott Straus, “Macro, Meso, and Micro Research on Genocide: Gains, Shortcomings, and Future Areas of Inquiry," Genocide Studies and Prevention 7, no.1 (2012), 62.

${ }^{94}$ Elizabeth Neuffer, The Key to My Neighbor's House: Seeking Justice in Bosnia and Rwanda (New York: Picador, 2001$), 94$. Neuffer notes that Rwanda once bore the moniker of "Switzerland of Africa" among its turbulent African neighbors because of Rwanda's marked lack of violence, crime, prostitution, and unrest under the Habyarimana regime.

${ }^{95}$ Taylor, Sacrifice as Terror, 157.

96 "Genocide, Rescue, and Prevention: Understanding and Fostering Rescue Behavior in the Face of Mass Killing," Yale Center for Bioethics, accessed July 6, 2015, http://www.google.com/url?sa=t\&rct=j\&q=\&esrc=s\&source=web\&cd=1\&ved=0 CB4QFjAA\&url=http\%3A\%2F\%2Felsinore.cis.yale.edu\%2Fgsp\%2Frescue\%2Fdownload\%2Fbioethics-rescue-behavior.pdf \&ei=ZNmaVcv8KISeNrL6qNAF\&usg=AFQjCNFW49ahRZ4VzKh5j0Q7pzngDNO8qg\&bvm=bv.96952980,d.eXY.

${ }^{97}$ See Ben Lieberman, "Nationalist Narratives, Violence between Neighbours and Ethnic Cleansing in BosniaHercegovina: A Case of Cognitive Dissonance?" Journal of Genocide Research 8, no. 3 (2006), 14 and Finkel and Straus, "Macro, Meso, and Micro," 63. 
interdisciplinary nature of genocide studies, and the widely varied historical, geographical, and circumstantial contexts of genocides make meaningful comparisons across cases difficult. This difficulty is partly allayed by viewing various avenues of inquiry as complementary to and not necessarily in competition with each other; bringing together various approaches of research to bear on single cases can lay the groundwork for more robust and productive comparisons across cases.

\section{Conclusion}

Recognizing the potential of religion to prevent and mitigate genocide is to acknowledge the capability of religious discourse, actors, and institutions to be positive rather than negative forces in conflicts. The typologies of othering, justification, and authorization represent ways of teasing out how religious rhetoric, myths, and actors promote genocide by providing recognizable narratives of ultimacy and raising the stakes of conflict, as well as pointing toward a strategy for prioritizing how religious traditions and church officials can act as a bulwark against genocide: for example, by humanizing rather than demonizing the other, utilizing religious rhetoric to provide counternarratives to ostensibly justified violence, exercising the moral reach of the church to condemn violence and promote reconciliation.

In addition to religious groups, institutions, and clergy assessing how their own religious traditions and clergy contribute to genocidal ideology and behavior, they can also partner with government and non-government organizations (NGOs) in reporting genocide triggers as part of an early warning system. One author argues that "religious groups are usually among the first people to learn of a religious persecution, especially against their own faith," ${ }^{98}$ making the cooperation with religious groups, who have intimate local knowledge of their communities, and groups tasked with forecasting genocide particularly advantageous in preventing genocides.

A trigger identified by The UN Office of the Special Adviser on the Prevention of Genocide (which launched a project in February 2010) that may forecast genocide is incendiary speech. The project indicates that "inflammatory speech often precedes mass atrocities, especially genocide... [and the outcome of their work] will result in (1) a blueprint for monitoring dangerous speech in situations at risk of genocide and mass atrocities, and (2) a methodology for gauging the dangerousness of specific speech acts." ${ }^{\prime \prime 9}$ As our discussion of religious rhetoric makes clear, such rhetoric can certainly constitute "dangerous speech." Monitoring religious rhetoric (written and spoken) is particularly integral to early warning systems because it is often "the first publicly available indication of a group's genocidal intentions...Rwandan 'Hutu Power,' and Serbian ultranationalism appeared years before the genocides those ideologies spawned." 100 In addition, local church officials can lend credibility as well as their local knowledge to NGOs in order to maximize the results of their activities. To date, it does not appear that such a forged partnership exists. The recognition of the capacity for religion to aid in genocide prevention, mitigation, and reconciliation is particularly important given the ineffectual, and at times nonexistent, international response to genocide.

For all that religion can accomplish in predicting genocide, without the political will, early warning systems can do nothing more than forecast potential genocide. Tragically, the Rwandan genocide could have been prevented or at least greatly mitigated if the international community had intervened. This makes it all the more imperative to bring to bear any and all resources, especially local ones, that are formidable enough to stymie, ameliorate, or even halt genocide once it commences. A critical part of these local resources are church officials and the institutional church; for example, Longman contends that "the involvement or resistance of religious institutions in genocide can have a profound impact on the success or failure of genocidal movements." 101

\footnotetext{
${ }^{98}$ John G. Heidenrich, How to Prevent Genocide: A Guide for Policymakers, Scholars, and the Concerned Citizen (Westport: Praeger Publishers, 2001), 78 (emphasis added).

99 "The Office of the Special Adviser on the Prevention of Genocide," United Nations, accessed April 3, 2013, http://www. un.org/en/preventgenocide/adviser/projects.shtml.

${ }^{100}$ Heidenrich, How to Prevent Genocide, 75 (emphasis added).

${ }^{101}$ Timothy Longman, Christianity and Genocide in Rwanda (New York: Cambridge University Press, 2010), 17 (emphasis
} 
Religion has and can continue to play a pivotal role in resisting genocide and in the healing process of victims of genocide, most notably by public condemnation of genocide and through heroic acts. This includes issuing official statements and engineering the sheltering or escape of victims of genocide, and in the aftermath of genocide, providing aid and lending support to reconciliation efforts. In this regard, one of the best known organizations is Catholic Relief Services (CRS). Yet it is likely that the most advantageous role religion can play in genocide is not in forecasting its perpetration, mitigating its effects, or assisting in post-genocide efforts, but in cultivating a cultural environment that reduces the possibility of genocidal propaganda taking root in the first place.

Post genocide, the identification of the systematic use of rape can bolster criminal court cases by adding any evidence presented to establish genocidal intent, acknowledging women's suffering in a legal context. Morally there is also a place for religion in affirming the dignity of women who are victims of rape as well as rebuking perpetrators of rape-as a pastoral duty to bear witness. Carol Rittner, noting that both the former Yugoslavia and Rwanda had substantial Roman Catholic populations and that the Vatican leadership often publicly comments on issues of sex and sexual morality, expresses her utter disappointment with the Vatican for failing to provide comfort to rape victims and women who were forcibly impregnated as well as for failing to unequivocally condemn the men who engaged in sexual violence. ${ }^{102}$ As a Catholic and member of the MidAtlantic (USA) Community of the Sisters of Mercy, she laments that she is still awaiting the "great voice... in Rome" to offer words of compassion to women of the world who have been violated, infected with HIV/AIDS, and forcibly impregnated and left to care for the children of their genocide perpetrators. ${ }^{103}$ She writes:

I can only conclude that the leadership of the Roman Catholic Church, the Pope, and his cardinals, archbishops, and bishops, unlike the God of Abraham, Isaac, and Jacob in Exodus 3:7-10, failed to witness the affliction of God's people (women) in Yugoslavia and Rwanda, failed to hear the cry of complaint God's people (women) uttered against the men who used rape as a weapon of war and genocide in Rwanda and Yugoslavia, and failed, failed utterly to know well what God's people (women) were suffering in the 1990s, and still suffer today. ${ }^{104}$

The public condemnation Rittner calls for is a moral imperative for the Church that is conducive to the cultivation of a culture that does not tolerate rape in peace or wartime, and it could conceivably assuage some of the guilt, shame, and ostracism that sexual assault victims endure from their fellow coreligionists.

Regardless of the trajectory of genocide studies and whether a scholar's work is primarily theoretical or not, I contend that the overarching goal of all approaches to genocide studies should ultimately have a pragmatic application: genocide detection, prevention, and mitigation. This is a commitment that enjoys agreement among pioneer scholars, such as Charny, and new scholars, such as Benita Sumita. Sumita argues that genocide studies should emphasize a "forward-looking perspective, one that distinguishes between academic [which tend toward explanatory models of genocide] and legal applications of the genocide framework [which tend toward models of prosecution], and seeks to advance genocide studies in a proactive and preventive way, rather than just as retrospectively." 105 This study is a contribution to this line of investigation. The typologies of the nexuses of religion and genocide and genocidal rape are strategies for accomplishing two aims. These tools are a first step to deciphering how religion and sexual violence buttress the intricate components of genocidal perpetration in service to the subsequent application of the insights that such an approach yields for genocide prevention, mitigation, and prosecution.

added).

102 Carol Rittner, "Rape, Religion, and Genocide: An Unholy Alliance," in Confronting Genocide: Judaism, Christianity, Islam, ed. Steven Leonard Jacobs (New York: Lexington Books, 2009), 302.

103 Ibid.

${ }^{104}$ Ibid. (emphasis in original).

${ }^{105}$ Adam Jones, ed., New Directions in Genocide Research (London and New York: Routledge, 2012), xxv. 
Bibliography

Appleby, R. Scott. The Ambivalence of the Sacred: Religion, Violence, and Reconciliation. Lanham: Rowan \& Littlefield Publishers, 2000.

Blok, Anton. "The Narcissism of Minor Differences." European Journal of Social Theory 1, no. 33 (1998): 33-56. https://doi.org/10.1177/136843198001001004

Brudholm, Thomas, and Thomas Cushman. "Introduction: The Religious in Responses to Mass Atrocity." In The Religious in Responses to Mass Atrocity: Interdisciplinary Perspectives, edited by Thomas Brudholm and Thomas Cushman, 1-20. New York: Cambridge University Press, 2009. https://doi.org/10.1017/CBO9780511575730

Burns, Charlene. More Moral Than God: Taking Responsibility for Religious Violence. Lanham: Rowman \& Littlefield Publishers, Inc., 2008.

Cassese, Antonio A., Guido Acquaviva, Mary Fan, and Alex Whitin, eds. International Criminal Law: Cases and Commentary. New York: Oxford University Press, 2011.

Des Forges, Alison. Leave None to Tell the Story: Genocide in Rwanda. New York: Human Rights Watch, 1999.

Finkel, Evgeny, and Scott Straus. "Macro, Meso, and Micro Research on Genocide: Gains, Shortcomings, and Future Areas of Inquiry." Genocide Studies and Prevention 7, no. 1 (2012): 56-67. https://doi.org/10.3138/gsp.7.1.56

Gort, Jerald D., Hendrick M. Vroom, and Henry Jansen, eds. Religion, Conflict and Reconciliation: Multifaith Ideals and Realities. Amsterdam: Rodopi B.V., 2002.

Gourevitch, Philip. We Wish to Inform You that Tomorrow We Will be Killed with Our Families: Stories from Rwanda. New York: Farrar, Straus \& Giroux, 1998.

Hatzfeld, Jean. Machete Season: The Killers in Rwanda Speak. Translated by Linda Coverdale. New York: Farrar, Straus, and Giroux, 2003.

Heidenrich, John G. How to Prevent Genocide: A Guide for Policymakers, Scholars, and the Concerned Citizen. Westport: Praeger Publishers, 2001

Jacobs, Steven Leonard. Confronting Genocide: Judaism, Christianity, Islam. New York: Lexington Books, 2009.

Jacobs, Steven Leonard. "Introduction: Genocide in the Name of God: Thoughts on Religion and Genocide." In Confronting Genocide: Judaism, Christianity, Islam, edited by Steven Leonard Jacobs, ix-xvii. New York: Lexington Books, 2009. https://doi.org/10.1053/j.pcsu.2009.01.001

Jones, Adam, ed. New Directions in Genocide Research. London and New York: Routledge, 2012.

Juergensmeyer, Mark. Global Rebellion: Religious Challenges to the Secular State, from Christian Militants to al Qaeda. Berkeley and Los Angeles: University of California Press, 2008.

Kippenberger, Hans. Violence as Worship: Religious Wars in the Age of Globalization. Stanford: Stanford University, 2011.

Lemarchand, René. “The Rwandan Genocide.” In Century of Genocide: Eyewitness Accounts \& Critical Views, edited by Samuel Totten, William S. Parsons, and Israel W. Charny, 404-22. New York and London: Garland Publishing, Inc., 1997.

Lieberman, Ben. "Nationalist Narratives, Violence between Neighbours and Ethnic Cleansing in Bosnia-Hercegovina: A Case of Cognitive Dissonance?" Journal of Genocide Research 8, no. 3 (2006): 295-309. https://doi.org/10.1080/14623520600950013

Lincoln, Bruce. Holy Terrors: Thinking about Religion after September 11. Chicago: The University of Chicago Press, 2006. https://doi.org/10.7208/chicago/9780226482071.001.0001

Little, David. "Studying 'Religious Human Rights': Methodological Foundations." In Religious Human Rights in Global Perspective, edited by Johan D. van der Vyver and John Witte, Jr. Hague: Martinus Nijhoff Publishers, 1996.

Longman, Timothy. "Christian Churches and Genocide in Rwanda." In In God's Name: Genocide and Religion in the Twentieth Century, edited by Omer Bartov and Phyllis Mack, 139-60. New York and Oxford: Berghahn Books, 2001.

Longman, Timothy. "Church Politics and the Genocide in Rwanda." Journal of Religion in Africa 31, no. 2 (2001): 163-86. https://doi.org/10.1163/157006601X00112

Longman, Timothy. Christianity and Genocide in Rwanda. New York: Cambridge University Press, 2010. 
Mamdani, Mahmood. When Victims Become Killers: Colonialism, Nativism, and the Genocide in Rwanda. Princeton: Princeton University Press, 2001.

McCullum, Hugh. The Angels Have Left Us: The Rwanda Tragedy and the Churches. Risk Book Series. Geneva: WCC Publications, 2004.

Miller, Alexandra A. "From the International Criminal Tribunal for Rwanda to the International Criminal Court: Expanding the Definition of Genocide to Include Rape." Penn State Law Review 108, no. 1 (2003): 349-73.

Mullins, Christopher W. "He Would Kill Me With His Penis": Genocidal Rape in Rwanda as a State Crime." Critical Criminology 17 (2009): 15-33. https://doi.org/10.1007/s10612-008-9067-3

Neuffer, Elizabeth. The Key to My Neighbor's House: Seeking Justice in Bosnia and Rwanda. New York: Picador, 2001.

Patterson, D. "Getting Rid of the G-d of Abraham: A Prerequisite for Genocide." In Confronting Genocide: Judaism, Christianity, Islam, edited by Steven Leonard Jacobs, 197-208. New York: Lexington Books, 2009.

Rakoczy, Susan. "Religion and Violence: The Suffering of Women." Agenda 61 (2004): 29-35.

Rittner, Carol. "Rape, Religion, and Genocide: An Unholy Silence." In Confronting Genocide: Judaism, Christianity, Islam, edited by Steven Leonard Jacobs, 291-306. New York: Lexington Books, 2009.

Rittner, Carol and John K. Roth. Rape: Weapon of War and Genocide. St. Paul: Paragon House, 2012.

Roger: Genocide Baby. Directed by Nick Andrews. 2011. UK: British Broadcasting Corporation. DVD. Sémelin, Jacques. Purify and Destroy. London: Hurst, 2007.

Smith, Robert W. "Genocide and the Politics of Rape." In Genocide Matters: Ongoing Issues and Emerging Perspectives, edited by Joyce Apsel and Ernesto Verdeja, 82-105. New York: Routledge, 2013.

Taylor, Christopher C. Sacrifice as Terror: The Rwandan Genocide of 1994. New York: Berg Publishers, 1999.

"A Gendered Genocide: Tutsi Women and Hutu Extremists in the 1994 Rwandan Genocide." PoLAR no. 22, 1 (1999): 42-54.

------.- "The Cultural Face of Terror in the Rwandan Genocide of 1994." In Annihilating Difference: The Anthropology of Genocide, edited by Alexander Laban Hinton, 137-78. Berkeley and Los Angeles: University of California Press, 2002. https://doi.org/10.1525/ california/9780520230286.003.0006

---. "Genocide and the Religious Imaginary in Rwanda." In The Oxford Handbook of Religion and Violence, edited by Mark Juergensmeyer, Margo Kitts, and Michael Jerryson, 268-79. New York: Oxford University Press, 2013.

Thompson, Allan. The Media and the Rwandan Genocide. Pluto Press: London, 2007."Translated 1992 speech of Leon Mugesera." Rwanda Gateway. Accessed October 10, 2013. http://www. rwandagateway.org/spip.php?article1340.

von Joeden-Forgey, Elisa. "Gender and the Future of Genocide Studies and Prevention." Genocide Studies and Prevention 7, no. 1 (2012): 89-107. https://doi.org/10.3138/gsp.7.1.89

Yale Center for Bioethics. "Genocide, Rescue, and Prevention: Understanding and Fostering Rescue Behavior in the Face of Mass Killing." Accessed July 6, 2015. http://www.google.com/url?s $\underline{a}=t \& r c t=j \& q=\& e s r c=s \& s o u r c e=w e b \& c d=1 \& v e d=0 C B 4 Q F j A A \& u r l=h t t p \% 3 A \% 2 F \% 2 F e l s i n o$ re.cis.yale.edu $\% 2 \mathrm{Fgsp} \% 2 \mathrm{Frescue} \% 2 \mathrm{Fdownload} \% 2 \mathrm{Fbioethics}-$ rescue-behaviorpdf\&ei $=\mathrm{ZN}$ maVcv8KISeNrL6qNAF\&usg=AFQjCNFW49ahRZ4VzKh5j0Q7pzngDNO8qg\&bvm=bv.9 6952980,d.eXY. 